\title{
Phenytoin intoxication induced by sulthiame in epileptic patients
}

\author{
G. W. HOUGHTON AND A. RICHENS \\ From the Department of Clinical Pharmacology, St. Bartholomew's Hospital, London, \\ and the National Hospital-Chalfont Centre for Epilepsy, Chalfont St. Peter, Bucks.
}

SYNOPSIS Routine estimation of serum phenytoin levels in patients newly admitted to a Special Centre for Epilepsy showed that $40 \%$ of those receiving sulthiame in addition to phenytoin had levels in the toxic range. Four long-stay patients became drug intoxicated when sulthiame treatment was started. Sulthiame appears to inhibit the hepatic hydroxylation of phenytoin.

Sulthiame (Ospolot) is a sulphonamide derivative with carbonic anhydrase inhibiting properties. It has been shown in animals (Wirth et al., 1961) to have anticonvulsant properties, like acetazolamide, but it lacks diuretic effect. It has become popular in Germany and, more recently, in England, for treating all types of major epilepsy. Early studies in patients (LaVeck et al., 1962; Liske and Forster, 1963; Gordon, 1964) showed that it was an effective anticonvulsant when given in combination with other drugs for major epilepsy. It has been used as sole treatment in only small numbers of patients, and has not been tested alone in a placebo-controlled trial. The incidence of adverse effects has been high in most trials (Gordon, 1964), and two recent studies have suggested one possible explanation for this. When sulthiame is added to existing phenytoin therapy, the serum level of the latter drug has been shown to rise, often to toxic levels (Olesen and Jensen, 1969). Inhibition of hepatic metabolism of phenytoin was suggested by the demonstration of an increased serum half-life of the drug (Hansen et al., 1968). Oleson and Jensen (1969), however, concluded that phenytoin metabolism was unaffected for they showed no consistent change in the urinary excretion of the major metabolite when sulthiame was added to their patients' treatment. They suggested an alternative explanation, that phenytoin bound to sites such as red cells might be displaced by sulthiame.

This interaction between the two drugs has two consequences. First, it may account entirely or in part for the anticonvulsant action of sulthiame and, second, it may lead to intoxication in patients who have been receiving phenytoin without adverse effect for a number of years. Although this latter effect is likely to be important when sulthiame is used, as it often is, as supplementary treatment in patients whose fits have been difficult to control and who are already receiving large doses of anticonvulsant drugs, the frequency with which it occurs in clinical practice has not been adequately assessed. The purpose of this paper is to evaluate the practical importance of this interaction in patients newly admitted for assessment in a Special Centre for Epilepsy, and to report our observations on four long-stay patients with severe epilepsy who were given sulthiame in an attempt to achieve better control of their fits.

\section{METHODS}

The National Hospital-Chalfont Centre for Epilepsy began to function as a Special Centre for Epilepsy in January 1972. Patients are admitted for short-term care for assessment of fits and employability, and for rehabilitation. In many cases, control of fits has been difficult to achieve and most patients are receiving two or more drugs on admission. Most patients are young, although a minimum age of 16 years is stipulated. During the first 15 months of its functioning 170 patients were admitted, of whom 137 were receiving phenytoin. Blood samples were taken from these patients about one week after admission 
at approximately 7.00 hours, before the first dose of drugs for that day. Serum phenytoin was estimated in these specimens by gas chromatography using a flash-methylation method which has been described in detail elsewhere (Houghton et al., 1972). In an inter-laboratory quality control scheme organized by us, this method has given consistent results, although on average about $4-8 \mu \mathrm{M}(1-2 \mu \mathrm{g} / \mathrm{ml}$.) higher than the mean of the 20 other participating laboratories. In our experience few patients with serum phenytoin levels below $100 \mu \mathrm{M}(25 \mu \mathrm{g} / \mathrm{ml}$.) show signs of phenytoin intoxication and we therefore regard this level as the upper limit of the therapeutic range. This is higher than the generally accepted upper limit of $80 \mu \mathrm{M}(20 \mu \mathrm{g} / \mathrm{ml}$.) (Buchthal et al., 1960). Patients with levels equal to or above $100 \mu \mathrm{M}(25 \mu \mathrm{g} / \mathrm{ml}$.) we have called 'intoxicated'.

In two patients who were on a combination of sulthiame and phenytoin, and who were clinically and biochemically intoxicated on admission, the serum half-life of phenytoin was estimated by giving an oral dose of $10 \mu \mathrm{Ci}$ carbon-labelled phenytoin (Radiochemical Centre, Amersham) in a specially prepared capsule containing a lactose excipient. Blood samples were taken 12 hourly for four days and the total radioactivity of the serum was estimated in a liquid scintillation counter. In these patients the 24 hour urinary excretion of phenytoin and its major metabolite, 5-(p-hydroxyphenyl)-5phenylhydantoin (HPPH), was estimated by gas chromatography, and the ratio of metabolite to parent drug (HPPH:DPH ratio) calculated. The method for phenytoin was similar to that for serum samples. HPPH was estimated by flash-methylation after acid hydrolysis of urine to release the metabolite from its conjugation with glucuronic acid. The patients were assessed clinically and biochemically on admission, and again four weeks after sulthiame treatment had been discontinued without any other drug change.

In a separate study, four long-stay patients in the Chalfont Centre were selected for treatment with sulthiame because each had poorly controlled major epilepsy and had not previously been tried on this drug. Each had been receiving phenytoin and at least two other anticonvulsant drugs in a constant dosage for several months before sulthiame treatment. Sulthiame was started at a dose of $200 \mathrm{mg} /$ day for two weeks, then increasing to $400 \mathrm{mg} / \mathrm{day}$. Serum phenytoin levels were estimated at frequent intervals after starting sulthiame treatment. Each of the four patients became clinically intoxicated and therefore the drug had to be withdrawn. Further measurements were made until the patients were back to their pre-trial state.

\section{RESULTS}

NEWLY ADMITTED PATIENTS Of the 137 patients receiving phenytoin treatment on admission, 20 were also taking sulthiame. The dose of phenytoin varied from 100 to $500 \mathrm{mg} / \mathrm{day}$, and that of sulthiame from 100 to $800 \mathrm{mg} /$ day. One patient, who had a toxic serum phenytoin level of $115 \mu \mathrm{M}(29 \mu \mathrm{g} / \mathrm{ml}$.), was receiving p-aminosalicylic acid and isoniazid for tuberculosis, and was therefore excluded because isoniazid is known to inhibit phenytoin metabolism (Kutt et al., 1966). It can be seen from Table 1 that $40 \%$ of patients receiving a combination of sulthiame

TABLE 1

INCIDENCE OF PHENYTOIN INTOXICATION IN NEW ADMISSIONS RECEIVING PHENYTOIN WITH OR WITHOUT SULTHIAME

\begin{tabular}{lcc}
\hline & \multicolumn{2}{c}{ Patients receiving } \\
\cline { 2 - 3 } & Phenytoin alone & Phenytoin + sulthiame \\
\hline Number of patients & 116 & 20 \\
Number intoxicated & 15 & 8 \\
$\%$ intoxicated & $13 *$ & $40^{*}$ \\
Mean serum phenytoin & $38 \mu \mathrm{M} \dagger$ & $66 \mu \mathrm{M} \dagger$ \\
level & $(9.5 \mu \mathrm{g} / \mathrm{ml})$. & $(16.5 \mu \mathrm{g} / \mathrm{ml})$. \\
Mean daily dose of & $285 \mathrm{mg}$ & $288 \mathrm{mg}$ \\
phenytoin & & \\
\hline
\end{tabular}

$* \chi^{2}=6.67, \mathrm{P}<0.01$.

$+\mathbf{P}<0.01, t$ test on logarithmically transformed data.

and phenytoin had serum phenytoin levels in the toxic range ( $\geqq 100 \mu \mathrm{M}, 25 \mu \mathrm{g} / \mathrm{ml}$.) whereas only $13 \%$ of patients not receiving sulthiame had toxic levels, and the difference between these values was significant. Most patients with a serum phenytoin level in the toxic range had clinical signs of intoxication. Despite an almost identical mean intake of phenytoin, the patients on a combined therapy had a mean serum phenytoin level $74 \%$ higher than those not on sulthiame. Serum phenytoin levels showed a lognormal distribution, and therefore Student's $t$ test has been applied to logarithmically transformed data. The mean values quoted are geometric means. Table 2 lists the patients who had levels in the toxic range. It can be seen that seven of the 15 patients intoxicated by phenytoin alone were receiving more than $300 \mathrm{mg} /$ day, 
TABLE 2

SERUM PHENYTOIN LEVELS AND DRUG DOSAGE IN INTOXICATED PATIENTS*

\begin{tabular}{|c|c|c|c|c|c|c|c|}
\hline \multirow{2}{*}{\multicolumn{2}{|c|}{$\begin{array}{l}\text { Patient } \\
\text { (age, sex) }\end{array}$}} & \multirow{3}{*}{$\begin{array}{c}\begin{array}{c}\text { Serum } \\
\text { phenytoin } \\
\mu M(\mu \mathrm{g} / \mathrm{ml} .)\end{array} \\
100(25)\end{array}$} & \multicolumn{5}{|c|}{ Drug treatment and dosage ( $m g /$ day) } \\
\hline & & & \multirow{2}{*}{$\begin{array}{c}\text { Phenytoin } \\
150\end{array}$} & \multirow{2}{*}{ Sulthiame } & Phenobarbitone & \multirow{2}{*}{$\frac{\text { Primidone }}{750}$} & \multirow[t]{2}{*}{ Others } \\
\hline J.R. & $(18 \mathrm{~F})$ & & & & - & & \\
\hline G.R. & $(23 \mathrm{~F})$ & $102(25 \cdot 5)$ & 400 & - & - & 750 & Carbamazepine 400 \\
\hline J.M. & $(42 \mathrm{M})$ & $107(27)$ & 300 & - & 一 & - & Pheneturide 600 , chlordiazepoxide 20 \\
\hline M.C. & $(22 \mathrm{M})$ & $110(27 \cdot 5)$ & 400 & - & 120 & - & \\
\hline F.C. & $(38 \mathrm{M})$ & $110(27 \cdot 5)$ & 500 & - & - & 750 & \\
\hline J.C. & $(34 \mathrm{M})$ & $112(28)$ & 300 & - & 180 & - & \\
\hline A.C. & $(25 \mathrm{M})$ & $112(28)$ & 300 & - & 150 & 一 & \\
\hline A.C. & $(18 \mathrm{M})$ & $114(28 \cdot 5)$ & 300 & - & - & - & Pheneturide 600 , carbamazepine 600 \\
\hline M.K. & (34 M) & $114(28 \cdot 5)$ & 500 & - & 90 & - & Carbamazepine 600 , diphenhydramine 25 \\
\hline C.R. & $(20 \mathrm{M})$ & $120(30)$ & 300 & - & - & - & \\
\hline V.A. & $(20 \mathrm{M})$ & $122(30 \cdot 5)$ & 350 & - & 180 & - & Carbamazepine 1,200 \\
\hline D.W. & $(19 \mathrm{M})$ & $171(43)$ & 300 & - & - & 750 & \\
\hline M.H. & $(34 \mathrm{~F})$ & $180(45)$ & 500 & - & 250 & - & \\
\hline R.V. & $(23 \mathrm{M})$ & $180(45)$ & 400 & - & 60 & - & Chlordiazepoxide 15 \\
\hline S.K. & $(21 \mathrm{M})$ & $195(49)$ & 300 & - & 120 & - & \\
\hline Mean & & $130(32 \cdot 5)$ & 353 & & & & \\
\hline L.W. & $(22 \mathrm{M})$ & $100(25)$ & 300 & 300 & - & - & Pericyazine $2 \cdot 5$ \\
\hline S.F. & $(17 \mathrm{M})$ & $104(26)$ & 200 & 600 & - & - & Diazepam $12 \cdot 5$ \\
\hline C.P. & $(18 \mathrm{M})$ & $108(27)$ & 300 & 600 & 180 & - & Ethosuximide 750 \\
\hline L.H. & $(26 \mathrm{M})$ & $128(32)$ & 300 & 400 & - & 750 & \\
\hline M.S. & (25 M) & $142(35 \cdot 5)$ & 300 & 400 & - & 750 & Diazepam 15 \\
\hline S.S. & $(25 \mathrm{~F})$ & $156(39)$ & 300 & 300 & 180 & - & \\
\hline P.H. & $(22 \mathrm{M})$ & $180(45)$ & 300 & 600 & - & 750 & \\
\hline A.F. & $(27 \mathrm{~F})$ & $190(47 \cdot 5)$ & 300 & 300 & - & - & \\
\hline Mean & & $138(34 \cdot 5)$ & 287 & & & & \\
\hline
\end{tabular}

* The upper group were receiving sulthiame while the lower group were not.

whereas none of the patients on combined treatment was doing so.

In order to examine the effect of sulthiame on serum phenytoin in patients on a standard dose of phenytoin, the data have been re-examined in patients receiving $300 \mathrm{mg} /$ day. Table 3 shows the results in the 83 patients included in this group, and Fig. 1 illustrates the distribution of serum phenytoin levels. Again there is a significant difference between the number of patients intoxicated and the mean serum phenytoin levels.

Two patients who were clinically intoxicated on admission and who were on combined treatment were selected for detailed study. The metabolism of phenytoin was examined by estimating the steady state serum phenytoin level, serum half-life, and urinary HPPH:DPH ratio before and after withdrawing sulthiame treatment without any other drug change. The results of these investigations are illustrated in Fig. 2 and are described in the following case reports.
PATIENT M.S.

This patient, a 25 year old Jewish male, was admitted with a six year history of epileptic fits after a fall from a horse which resulted in a left extradural haemorrhage with contusion of the underlying brain. He was receiving the following drugs on admission: phenytoin $300 \mathrm{mg} / \mathrm{day}$, primidone $750 \mathrm{mg} / \mathrm{day}$, diazepam $15 \mathrm{mg} / \mathrm{day}$, and sulthiame $400 \mathrm{mg} /$ day. He exhibited typical cerebellar signs of phenytoin intoxication-namely, coarse nystagmus, ataxia, and slurred speech. Investigations were as follows: serum phenytoin $142 \mu \mathrm{M}(35.5 \mu \mathrm{g} / \mathrm{ml}$.); phenytoin half-life 77 hours; urinary HPPH:DPH ratio 13.5. Sulthiame was withdrawn when these investigations had been completed and the patient was re-examined four weeks later. His clinical signs had largely disappeared although he still has some residual ataxia and nystagmus at the time of writing, eight months after stopping sulthiame. Repeat investigations were as follows: serum phenytoin $56 \mu \mathrm{M}(14 \mu \mathrm{g} / \mathrm{ml}$.$) ;$ phenytoin half-life 41.2 hours; urinary HPPH:DPH ratio $40 \cdot 2$. His fits subsequently became less well controlled and so the dose of phenytoin was increased to $400 \mathrm{mg}$ /day. Serum phenytoin estimations two weeks and 10 weeks later gave levels of $69 \mu \mathrm{M}$ 


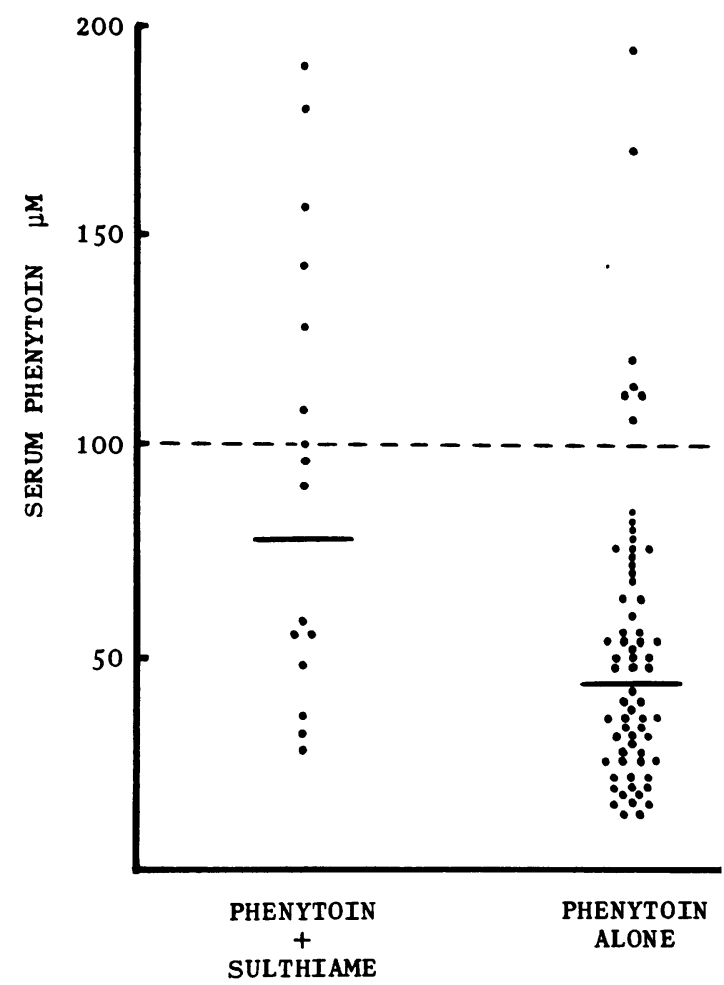

FIG. 1. Distribution of serum phenytoin levels in patients receiving $300 \mathrm{mg} /$ day phenytoin, with or without the addition of sulthiame. The upper limit of the therapeutic range is marked with a dashed line. Horizontal bars represent the mean values, based on logarithmically transformed data.

$(17 \mu \mathrm{g} / \mathrm{ml}$.) and $60 \mu \mathrm{M}(15 \mu \mathrm{g} / \mathrm{ml}$.) respectively. Fit control was improved.

\section{PATIENT P.H.}

This patient, a 22 year old Caucasian male with a right posterior temporal electroencephalographic (EEG) focus, was so ataxic on admission that he was having to walk with two walking sticks. He showed gross nystagmus, incoordination, and slurred speech, and complained of double vision. He was receiving phenytoin $300 \mathrm{mg} /$ day, primidone $750 \mathrm{mg} /$ day, and sulthiame $600 \mathrm{mg} /$ day. Initial investigations were as follows: serum phenytoin $180 \mu \mathrm{M}(45 \mu \mathrm{g} / \mathrm{ml}$.); phenytoin half-life 79.4 hours; urinary HPPH:DPH ratio $4 \cdot 6$. Sulthiame was abruptly withdrawn. Four weeks later he was considerably improved and no longer needed walking sticks. Investigations at this time were as follows: serum phenytoin $112 \mu \mathrm{M}$
TABLE 3

INCIDENCE OF PHENYTOIN INTOXICATION IN NEW ADMISSIONS RECEIVING 300 MG PHENYTOIN/DAY, WITH OR WITHOUT SULTHIAME

\begin{tabular}{lcc}
\hline & \multicolumn{2}{c}{ Patients receiving } \\
\cline { 2 - 3 } & Phenytoin alone & Phenytoin +sulthiame \\
\hline Number of patients & 67 & 16 \\
Number intoxicated & 7 & 7 \\
$\%$ intoxicated & $10^{*}$ & $44^{*}$ \\
Mean serum phenytoin level & $44 \mu \mathrm{M} \dagger$ & $78 \mu \mathrm{M} \dagger$ \\
& $(11 \mu \mathrm{g} / \mathrm{ml})$. & $(19 \cdot 5 \mu \mathrm{g} / \mathrm{ml})$.
\end{tabular}

$* \chi^{2}=6.90, \mathrm{P}<0.01$.

$+\mathrm{P}<0.01, t$ test on logarithmically transformed data.

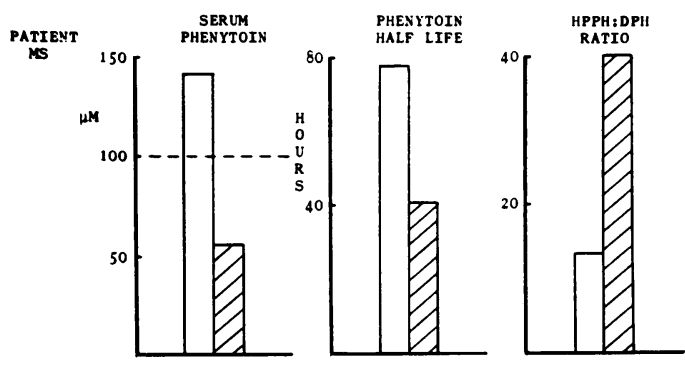

$\underset{\text { PAT }}{\text { PATIENT }}$
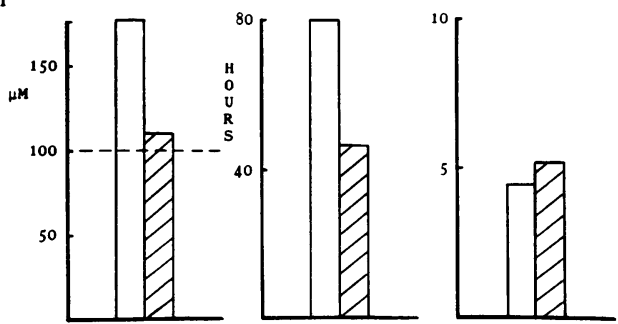

FIG. 2. Serum phenytoin levels, phenytoin half-lives, and HPPH: DPH ratios in two patients on combined treatment with phenytoin and sulthiame, and again four weeks after withdrawal of the latter drug.

$(28 \mu \mathrm{g} / \mathrm{ml}$.); phenytoin half-life 45.6 hours; urinary HPPH:DPH ratio 5.2. As the serum phenytoin level remained above the therapeutic range, a reduction of the dose of phenytoin to $200 \mathrm{mg} /$ day was made, without loss of fit control. His serum phenytoin level two weeks later was $39 \mu \mathrm{M}(9 \cdot 5 \mu \mathrm{g} / \mathrm{ml}$.), and he had then lost the clinical signs of intoxication.

\section{LONG-STAY PATIENTS}

The results of serial estimations of serum phenytoin in the four patients treated with sulthiame 
are shown in Fig. 3. The patients are briefly described in the following case reports.

\section{PATIENT R.M.}

This patient was a 26 year old male who had developed major epilepsy when he was five years old. His maternal uncle died when five years old from status epilepticus. Recent EEG investigations had shown bilateral spikes and slow waves, of larger amplitude over the left hemisphere and occasionally showing phase reversal over the anterior temporal region. He had frequent attacks of generalized convulsions, and numerous smaller attacks in which he fell but did not convulse. He was receiving phenytoin $300 \mathrm{mg} /$ day, primidone $1,250 \mathrm{mg} /$ day, pheneturide $400 \mathrm{mg} /$ day, ethosuximide $750 \mathrm{mg} /$ day, and diazepam $10 \mathrm{mg} /$ day. The introduction of sulthiame $200 \mathrm{mg} /$ day resulted in an apparent decrease in frequency of

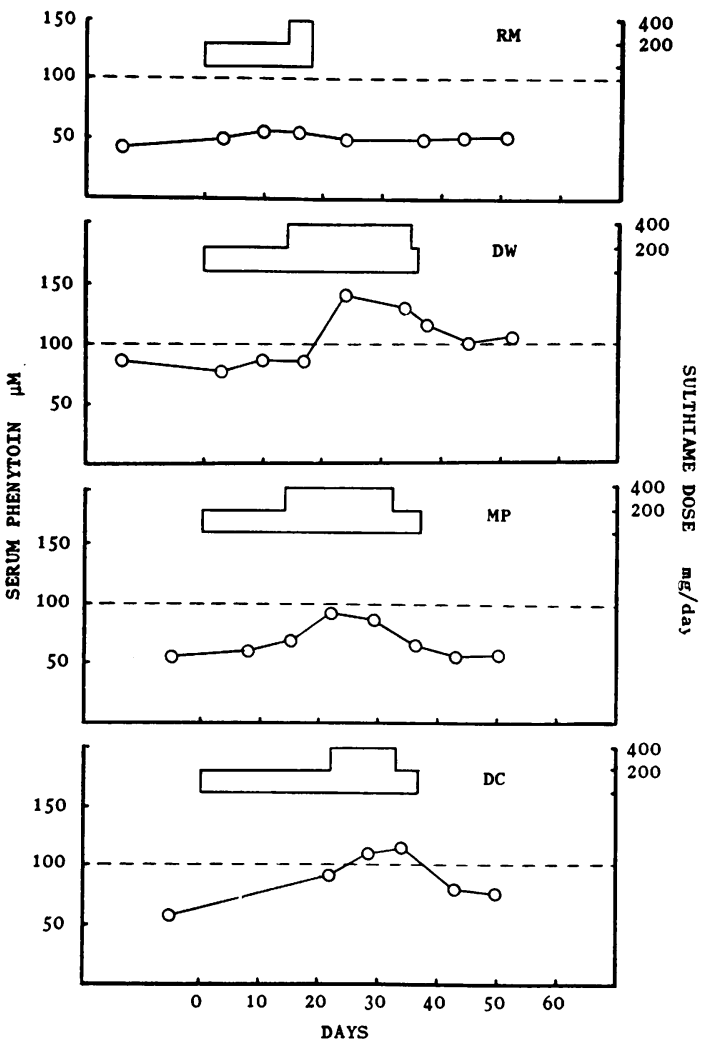

FIG. 3. Serum phenytoin levels in four long-stay patients who were treated with sulthiame. The upper limit of the therapeutic range for serum phenytoin is marked with a dashed line. fits, but, shortly after increasing the dose to $400 \mathrm{mg}$ / day, he became unable to work, drowsy, and slow of comprehension. He spent most of the day sleeping, and therefore the drug had to be withdrawn. Despite his being clinically intoxicated, his serum phenytoin level rose only slightly from a control level of $42 \mu \mathrm{M}$ $(10.5 \mu \mathrm{g} / \mathrm{ml}$.). He gradually returned to his normal state over the next two weeks.

\section{PATIENT D.W.}

This 25 year old male developed fits at the age of 12 years. The attacks were presumed to be idiopathic, although his head was often turned to the right in an attack. EEG recordings showed bilateral symmetrical spikes and slow waves, frequently coming in paroxysms. His fits varied in pattern from brief absences without falling, to attacks in which he fell unconscious but did not convulse. They occurred several times daily despite drug treatment which included phenytoin $300 \mathrm{mg} /$ day, primidone 1,000 $\mathrm{mg}$ /day, pheneturide $600 \mathrm{mg} / \mathrm{day}$, and diazepam 4 $\mathrm{mg} /$ day. Sulthiame treatment was started and continued for 36 days but at the end of this period he developed nystagmus and became ataxic, drowsy, withdrawn, and had poor comprehension of simple commands. Soon after starting treatment, he began to hyperventilate and developed tenderness over the testicles and vas deferens. Both these symptoms subsided when the drug was withdrawn. Fit frequency appeared to be little altered during sulthiame treatment. His initial serum phenytoin level was $85 \mu \mathrm{M}$ $(21 \mu \mathrm{g} / \mathrm{ml}$.), and by the 24 th day of treatment a toxic level of $140 \mu \mathrm{M}(35 \mu \mathrm{g} / \mathrm{ml}$.) was recorded.

\section{PATIENT M.P.}

This patient was a 29 year old female who developed major fits at the age of 12 years. A left sided parietal lesion from birth trauma was suggested by rightsided facial twitching during minor attacks, and by an asymmetrical distribution of spikes and slow waves in the EEG. As well as minor attacks, she had frequent major fits, often several in a short time. She was receiving phenytoin $300 \mathrm{mg} / \mathrm{day}$, primidone $750 \mathrm{mg} /$ day, and diazepam $20 \mathrm{mg} / \mathrm{day}$. Addition of sulthiame appeared to lessen the frequency of her attacks but, by the 32nd day, she was becoming ataxic and had developed nystagmus and hyperventilation. Sulthiame was therefore tailed off. Her serum phenytoin level had risen from $54 \mu \mathrm{M}(13.5$ $\mu \mathrm{g} / \mathrm{ml}$.) to $90 \mu \mathrm{M}(22 \cdot 5 \mu \mathrm{g} / \mathrm{ml}$.) on the 22 nd day.

\section{PATIENT D.C.}

This 33 year old female developed severe major fits of unknown cause at the age of 11 years. Right- 
sided twitching occurred in some of the shorter attacks, but EEG recordings had shown only diffuse slow and sharp waves. She had twice been in status epilepticus, when 24 years and 29 years of age. She was receiving phenytoin $300 \mathrm{mg} /$ day, phenobarbitone $150 \mathrm{mg} /$ day, and carbamazepine $600 \mathrm{mg} /$ day. Sulthiame treatment led to a reduction in the frequency and severity of her fits, but by the 32nd day she had become drowsy, muddled, uncooperative, and ataxic, and had developed nystagmus and slurred speech. Sulthiame was therefore tailed off. Her initial serum phenytoin level was $58 \mu \mathrm{M}(14.5$ $\mu \mathrm{g} / \mathrm{ml}$.) but by the 34th day a level of $112 \mu \mathrm{M}$ $(28 \mu \mathrm{g} / \mathrm{ml}$.) was recorded.

\section{DISCUSSION}

We have confirmed the findings of Hansen et al. (1968) and Olesen and Jensen (1969) that sulthiame causes an elevation of serum levels of phenytoin. In our newly admitted patients this elevation averaged $74 \%$, and was sufficient to produce a risk of phenytoin intoxication three times greater in patients on combined treatment than in those on phenytoin alone. Indeed, $40 \%$ of patients receiving sulthiame were phenytoin intoxicated. It can be argued that the population we have studied is not representative of the epileptic population in general, and that they might be more at risk to drug intoxication. Certainly the patients admitted to the National HospitalChalfont Centre for Epilepsy have problems, often with their fits, but it should be noted that the average phenytoin intake of the 136 patients receiving the drug was $285 \mathrm{mg}$, which is slightly less than the standard dose in common use. The daily intake was almost identical in the two groups in Table 1, and differences in phenytoin dose cannot, therefore, account for the higher serum phenytoin level in patients on sulthiame. This becomes even more obvious when analysis is confined to those patients receiving the standard dose of $300 \mathrm{mg} /$ day of phenytoin (Table 3). Indeed, the differences between the two groups become even greater. It seems that the dose of phenytoin required to produce intoxication in a group of patients is much less when sulthiame also is present. It can be seen from Table 2 that several patients who were intoxicated in the absence of sulthiame were taking more than the standard dose of phenytoin.

One point that emerges from this work is that estimation of serum phenytoin levels contributes greatly to the management of drug therapy. Altogether 23 of our patients were phenytoin intoxicated on admission, an overall incidence of $17 \%$. Most of these patients had been referred to the Centre by leading neurological units and therefore it must be assumed that diagnosing phenytoin intoxication is not as straightforward as is often maintained. This difficulty can be largely overcome by routine monitoring of serum phenytoin in patients at risk, particularly in those who are receiving sulthiame in addition. Before contemplating treatment with this latter drug, it would perhaps be wise to estimate the patient's phenytoin level, for in our experience a patient with anything more than a low therapeutic level (up to $50 \mu \mathrm{M}, 12.5 \mu \mathrm{g} / \mathrm{ml}$.) stands a considerable chance of developing intoxication. If sulthiame continues to become more popular as a supplement to anticonvulsant therapy without careful clinical and biochemical observation of the patient, an appreciable morbidity will result. Quite apart from the obvious effects of intoxication, most of the other adverse effects of phenytoin are related in degree to the circulating level of the drug.

One of our long-stay patients (R.M.) who was put on sulthiame became clinically severely drug intoxicated despite a minimal increase in serum phenytoin level (Fig. 3). He was receiving substantial doses of four other drugs-namely, primidone, pheneturide, ethosuximide, and diazepam-and therefore the question arises whether the metabolism of these other drugs might also be inhibited. A slight increase in serum phenobarbitone was shown by Olesen and Jensen (1969), and therefore it is possible that an increase in serum phenobarbitone (derived from primidone) may have accounted for this patient's symptoms. An alternative explanation of the discrepancy between R.M.'s clinical state and phenytoin level is that sulthiame itself was producing the signs of intoxication. It is not possible to decide which explanation is the correct one until more is known about the effect of sulthiame on the metabolism of other drugs. We are at present investigating this. Two of our four longstay patients developed obvious hyperventilation, and one complained of tenderness over the testicles and vas deferens. We have recently encountered this latter symptom in a normal 
volunteer taking sulthiame for research purposes, but it has not, to the best of our knowledge, been reported previously.

The considerable effect that sulthiame has on serum phenytoin levels raises the question of whether sulthiame is an anticonvulsant in its own right, or whether it acts through its interference with phenytoin (and possibly other drug) metabolism. It is not possible to answer this question on the available evidence, but certainly an average increase of $74 \%$ in the serum phenytoin level would be expected to produce a substantial improvement in fit control, regardless of any additional effect of sulthiame itself. Although in some trials it has been given to small numbers of patients as the sole treatment, none of these studies has been performed with a double-blind placebo-controlled design (Green and Kupferberg, 1972), and therefore it must still be regarded as an open question whether or not sulthiame has anticonvulsant properties of its own in man.

The mechanism of the interaction has been disputed. Hansen et al. (1968) found an increase in the serum half-life of a tracer dose of radioactive phenytoin, and considered that sulthiame, or one of its metabolites, inhibits the hydroxylase enzyme in the liver which is responsible for converting phenytoin to its inactive metabolite, HPPH. On the other hand, Olesen and Jensen (1969) found no consistent change in the 24 hour urinary excretion of HPPH. Our preliminary results in two patients, M.S. and P.H. (Fig. 2), have confirmed the marked effect of sulthiame on the serum half-life of phenytoin, and in addition have shown that the HPPH:DPH ratio increases-that is, changes in favour of the metabolite-when sulthiame treatment is stopped. We consider that this ratio is a more useful measure of phenytoin metabolism than estimating the total daily excretion of $\mathrm{HPPH}$, for the latter varies considerably from day to day and is dependent upon the accuracy with which the patient's urine is collected over 24 hours. A change in the HPPH:DPH ratio reflects a change in the activity of the hepatic hydroxylase enzyme, and thus our evidence supports the view of Hansen et al. (1968) that sulthiame (or one of its metabolites) inhibits this enzyme system. We are investigating this problem further.

We thank Dr. John Laidlaw for allowing us to study his patients, and the nursing staff at the National Hospital-Chalfont Centre for Epilepsy for their cooperation. This work was supported by the Epilepsy Research Fund, the E. M. Reynolds Research Fund at the Chalfont Centre, and the Royal Society.

\section{REFERENCES}

Buchthal, F., Svensmark, O., and Schiller, P. J. (1960). Clinical and electroencephalographic correlations with serum levels of diphenylhydantoin. Archives of Neurology, 2, 624-630.

Gordon, N. (1964). The use of Ospolot in the treatment of epilepsy. Epilepsia, 5, 68-73.

Green, J. R., and Kupferberg, H. J. (1972). Sulthiame. In Antiepileptic Drugs, pp. 477-485. Edited by D. M. Woodbury, J. K. Penry, and R. P. Schmidt. Raven Press: New York.

Hansen, J. M., Kristensen, M., and Skovsted, L. (1968). Sulthiame (Ospolot) as inhibitor of diphenylhydantoin metabolism. Epilepsia, 9, 17-22.

Houghton, G. W., Latham, A. N., and Richens, A. (1973). Difference in the central actions of phenytoin and phenobarbitone in man, measured by critical flicker fusion threshold. European Journal of Clinical Pharmacology, 6, $57-60$.

Kutt, H., Winters, W., and McDowell, F. H. (1966). Depression of parahydroxylation of diphenylhydantoin by antituberculosis chemotherapy. Neurology (Minneap.), 16, 594-602.

LaVeck, G. D., de la Cruz, F., and Thomas, D. B. (1962). Clinical evaluation of a new anticonvulsant, sulthiame. Neurology (Minneap.), 12, 923-928.

Liske, E., and Forster, F. M. (1963). Clinical evaluation of the anticonvulsant effects of sulthiame. Journal of New Drugs, 3, 32-36.

Oleson, O. V., and Jensen, O. N. (1969). Drug-interaction between sulthiame (Ospolot $(B)$ and phenytoin in the treatment of epilepsy. Danish Medical Bulletin, 16, 154-158.

Wirth, W., Hoffmeister, F., Friebel, H., and Sommer, S. (1961). The pharmacology of Ospolot. German Medical Monthly, 6, 309-313. 